Annals of Warsaw University of Life Sciences - SGGW

Land Reclamation No 45 (1), 2013: 85-95

(Ann. Warsaw Univ. of Life Sci. - SGGW, Land Reclam. 45 (1), 2013)

\title{
Water budget of the Zdworskie Lake in 2008-2012 period
}

ZBIGNIEW POPEK ${ }^{1}$, MICHAŁ WASILEWICZ ${ }^{1}$, AGNIESZKA BAŃKOWSKA ${ }^{1}$, ANDRZEJ BOCZON' ${ }^{2}$

${ }^{1}$ Department of Water Engineering, Faculty of Civil and Environmental Engineering, Warsaw University of Life Sciences - SGGW

${ }^{2}$ Department of Forest Ecology, Forest Research Institute

\begin{abstract}
Water budget of the Zdworskie Lake in 2008-2012 period. The paper presents the results of water balance calculations for the Zdworskie Lake, Poland, based on meteorological and hydrological data of 2008-2012 period. Meteorological data have come from automatic measurement station located near Łąck in a distance of about 7.5 kilometer from geometric center of the Zdworskie Lake. The station is a part of the monitoring system of The State Forests National Forest Holding. Hydrological data has been collected from five water-gauging stations located in the Wielka Struga River catchment to which belongs the Zdworskie Lake. The water-gauging stations has been established by Department of Water Engineering of Warsaw University of Life Sciences - SGGW within monitoring net constructed as a part of the Restoration Programme of the Lakes in the Łack Commune, Płock district. Water balance calculations revealed that throughout the analyzed period the retained water amount in $\mathrm{Zd}$ worskie Lake should be much larger than it was actually observed. Groundwater level fluctuations observed in one of the water-gauge sections together with geological conditions in the immediate lake catchment area suggest periodic outflow of the lake water into the ground. In the years 2008-2012 the annual loss of lake water caused by the groundwater alimentation varied ranging from about 761,000 to $2,078,000 \mathrm{~m}^{3}$.
\end{abstract}

Key words: water balance of lake, lake alimentation, the Zdworskie Lake

\section{INTRODUCTION}

Terms of supply and exchange of water have a major impact on the ecological condition in the lake. The natural variability of hydrological conditions requires that hydrological studies should be conducted for a long time. However, even short-term hydrological observation cycle allows to draw general conclusions on the water balance of the lake.

Hydrological studies in the Wielka Struga River catchment and in the Zdworskie Lake have been taken under the Restoration Programme of Lakes in the Łack Commune. The immediate need for the development of the Programme was the hydrological drought in 2003, which caused about $40 \mathrm{~cm}$ water-level fall in the Zdworskie Lake. It resulted in denuding the bottom of the lake on a large area and mass fish deaths (Kawałczewska 2009). Together with hydrological monitoring programme water quality and sediments chemistry investigations were started and number of lake restoration measures were taken (Bańkowska and Wasilewicz 2008; Wiśniewski 2009; Bańkowska et al. 2010). The most important actions 
which have improved the water balance of the lake was the channel seal of the Wielka Struga River in order to reduce the outflow of water into the deeper layers of groundwater (hydrogeological window) and artificial recharge of the lake using transit pipeline from the Dobrzykowski Canal (Popek 2009).

\section{MATERIAL AND METHODS}

The Zdworskie Lake, located in the Ląck Commune, district of the Płock, is the largest lake in the Łackie Lakeland and the largest in the Mazovian Voivodeship. The area of the lake is 342.9 ha, average depth $2.13 \mathrm{~m}$ and maximum depth $5.5 \mathrm{~m}$. The shoreline of the lake $9,970 \mathrm{~m}$ long is underdeveloped - the rate of development is 1.47. The maximum length of the lake is $3,590 \mathrm{~m}$, and the maximum width $-1,435 \mathrm{~m}$. For the normal water surface elevation of $79.20 \mathrm{~m}$ above sea level the volume of water in the lake is about 7.33 million $\mathrm{m}^{3}$.

The Zdworskie Lake is a polymictic reservoir, located on the route of the Wielka Struga River (Fig. 1). The total catchment area of the lake is $47.1 \mathrm{~km}^{2}$, the catchment of the Wielka Struga River in the mouth section of the lake covers an area of $27.6 \mathrm{~km}^{2}$. The remaining part of $19.5 \mathrm{~km}^{2}$ belongs to the immediate catchment of the lake with three small periodic streams (shown in Figure 1 as streams A, B and C). There is also an additional source of water - artificial supply from the Dobrzykowski Canal. Water is beeing pumped by a pipeline with a length of $7.8 \mathrm{~km}$ and a diameter of $225 \mathrm{~mm}$ from station in the Dobrzyków.
The maximum flow rate of the pipeline is $40 \mathrm{l} \cdot \mathrm{s}^{-1}$ (Popek 2009).

The Wielka Struga River catchment lies in the part of the country with the lowest amount of annual rainfall. In 1961-2000 the average annual rainfall was $527 \mathrm{~mm}$, of which $196 \mathrm{~mm} \mathrm{(37 \%}$ of annual rainfall) precipitated in the first half of the year (November-April) and $331 \mathrm{~mm}(63 \%$ of annual rainfall) in the last half of the year (May-October) (Lenart and Popek 2009). At the same time there are large water losses due to evaporation which are comparable to the average amount of annual rainfall. According to Gutry-Korycka (1978) in the Wielka Struga River catchment evapotranspiration during 1931-1960 was about $500-550 \mathrm{~mm}$. However, the estimated amount of evaporation from the surface of the water in 1951-1970 was about $547 \mathrm{~mm}$ (IMGW 1987). Unfavourable weather conditions cause that the average annual unit outflow $\left(q_{S Q}\right)$ of the catchments located in this area is also low - in 1951-1970 $q_{S Q}$ value of $2.5-3.01 \cdot \mathrm{s}^{-1} \cdot \mathrm{km}^{-2}$ was reported (IMGW 1987).

A systematic hydrological study started in autumn 2007. There were set five gauging stations: two in the Wielka Struga River to control water levels of main inflow and outflow of the lake and three on streams A, B and C, with periodic water supply from the immediate catchment of the lake (Fig. 1). In cross-section measurements of water level $(H)$ were carried out continuously with the time step of 1 hour. Flow rate $(Q)$ was periodically measured and discharge curve determined, i.e. the relationship $Q$ $=f(H)$. The discharge curve equation was used to compute for momentary val- 
ues of $H_{i}$ (measured with time step of 1 hour) fitting discharge rate $-Q_{i}\left[\mathrm{~m}^{3} \cdot \mathrm{s}^{-1}\right]$. This was the basis for calculations of the outflow volume passing through the observed gauging cross-section in a given time period. Total volume of outflow $\left(V_{k}\right)$ in each month of the hydrological year can be calculated from the formula:

$$
V_{k}=\frac{\sum_{j=1}^{j=n} \sum_{i=1}^{i=24} Q_{i} \cdot 3,600}{n \cdot 86,400}
$$

where:

$V_{k}$ - monthly outflow volume $\left[\mathrm{m}^{3}\right]$, $Q_{i}$ - the flow rate in hourly intervals $\left[\mathrm{m}^{3} \cdot \mathrm{s}^{-1}\right]$, $n$ - the number of days in a month.

The volume of water delivered per month to the Zdworskie Lake as a result of artificial recharge was based on a water-meter indication installed in the pumping station in the Dobrzyków.

Water balance of the Zdworskie Lake was done for monthly intervals by the following formula (Wiśniewski et al. 2007):

$$
\left(H_{d}-H_{o}\right)+\left(P-E_{w}\right)= \pm \Delta R
$$

where the individual components expressed in [mm] mean:

$H_{d}$ - surface inflow to the lake,

$H_{O}$ - surface outflow from the lake,

$P$ - precipitation,

$E_{w}$ - evaporation of water table of the lake,

$\Delta R$ - retention change in the lake.

The layer thickness of the surface inflow to the lake $\left(H_{d}\right)$ and surface outflow from the lake $\left(H_{O}\right)$ was determined for the consecutive months of the hydrological year according to the following formula:

$$
H_{d}=\frac{1,000 \cdot \sum V_{k d}}{F_{j}}
$$

$$
H_{o}=\frac{1,000 \cdot V_{k o}}{F_{j}}
$$

where:

$\sum_{\text {the }} V_{k d}$ - the total volume of inflow to the Wielka Struga River, streams A, B and $\mathrm{C}$, and the pumping station in the Dobrzyków $\left[\mathrm{m}^{3}\right]$,

$\sum V_{k o}$ - the total volume of outflow from the lake in gauge cross-section the Wincentów $\left[\mathrm{m}^{3}\right]$,

$F_{j}-$ lake area $\left[\mathrm{m}^{2}\right]$.

The amount of monthly precipitation (P) in the formula (1) was determined from measurements recorded by an automatic weather station of The State Forests National Forest Holding in Lack, in a distance of about $7.5 \mathrm{~km}$ from the geometric center of the Zdworskie Lake. This station is equipped with electronic pluviometer $\mathrm{OP} 5 \mathrm{G}$, allowing for automatic continuous precipitation measurements (with the time step of 1 hour). However, the amount of evaporation from the water surface $\left(E_{w}\right)$ was determined from the formula Penman-Monteith (Allen et al. 1998):

$E T_{o}=\frac{0.408 \Delta\left(R_{n}-G\right)+\gamma \frac{900}{T+273} u_{2}\left(e_{s}-e_{a}\right)}{\Delta+\gamma(1+0.34) u_{2}}$ 
where:

$E T_{O}$ - reference evapotranspiration $\left[\mathrm{mm} \cdot \mathrm{day}^{-1}\right]$,

$\Delta$ - tangent of angle of slope vapour pressure curve $\left[\mathrm{pa}^{\circ} \mathrm{C}^{-1}\right]$,

$R_{n}$ - net radiation $\left[\mathrm{MJ} \cdot \mathrm{m}^{-2} \cdot \mathrm{day}^{-1}\right]$,

$G$ - soil heat flux density $\left[\mathrm{MJ} \cdot \mathrm{m}^{-2} \cdot\right.$ day $\left.^{-1}\right]$,

$\gamma$-psychrometric constant $\left[\mathrm{pa}^{\circ}{ }^{\circ} \mathrm{C}^{-1}\right]$,

$T$ - mean daily air temperature at $2 \mathrm{~m}$ height $\left[{ }^{\circ} \mathrm{C}\right]$,

$u_{2}-$ wind speed at $2 \mathrm{~m}$ height $\left[\mathrm{m} \cdot \mathrm{s}^{-1}\right]$,

$e_{s}$-saturated vapour pressure $[\mathrm{kPa}]$,

$e_{a}-$ actual vapour pressure $[\mathrm{kPa}]$.

Net radiation $\left(R_{n}\right)$ is reduced by the amount of long-wave radiation and albedo in determining the daily values of evaporation. The parameters in equation (4) were also determined from observations made at the weather station in Łąck. These data were collected and processed by the Department of Forest Ecology, Forest Research Institute (FRI) in Warsaw. Results of the lake water balance calculations according to the formula (1) were compared with actual changes of retention in the Zdworskie Lake computed basing on changes in the lake water level in the analyzed periods.

\section{RESULTS AND DISCUSSION}

In the Wielka Struga River catchment and in the Zdworskie Lake hydrological conditions were variable, largely dependent on the amount of rainfall, the sum of half-yearly and annual summarized in Table 1. During the study period 2008-2012 the amount of annual rainfall was much higher than the average in multi-year period 1971-2000 (Table 1), never theless intense outflow of water from the Wielka Struga River catchment occurred only in 2010-2011, when the total annual rainfall exceeded the long-period average of about $100 \mathrm{~mm}$. This is evidenced by the half-yearly and annual average unit outflow $\left(q_{S O}\right)$ of the Wielka Struga River catchment (Table 2), which were 3.63 and $4.441 \cdot \mathrm{s}^{-1} \cdot \mathrm{km}^{2}$, respectively in 2010 and 2011. They were clearly higher than average $q_{S Q}$ in multi-year period 1951-1970 $\left(2.5-3.01 \cdot \mathrm{s}^{-1}\right.$, as reported by IMGW (1987). However, in 2008 and 2009 the outflow from the Wielka Struga River catchment was very small - annual $q_{S Q}$ values were $1.3-1.41 \cdot \mathrm{s}^{-1} \cdot \mathrm{km}^{-2}$. In $2012 q_{S Q}$ reached extremely low values of only $0.91 \cdot \mathrm{s}^{-1} \cdot \mathrm{km}^{-2}$.

Water supply conditions of the Zdworskie Lake depend not only on the annual average unit outflow $\left(q_{S Q}\right)$ but also on the evenly distribution of the outflow from the catchment. The data compiled in Table 2 show that in the winter half-year the outflow from the Wielka Struga River catchment is always significantly higher than in the summer half-year. The most balanced outflow occurred in 2010 . However, in the remaining hydrological years the annual uneven distribution of the outflow is much higher. The outflow from the catchment in the winter half-year of 2008, 2009 and 2012 was approximately 4-5 times larger than in the summer half-year, while in 2011 nearly 10 times larger.

The Wielka Struga River is the main natural source of water for the Zdworskie Lake. Table 3 shows the amount of water supplied to the lake by the Wielka Struga River and other sources. As mentioned earlier, streams A, B and C have carried small amounts of water only periodically, so they had little influence on the lake supply. Significant amount of water was 
TABLE 1. The sum of half-year and annual amount of rainfall in 2008-2012 compared to multi-year period 1961-2000 (Forest Research Institute data; Lenart and Popek 2009)

\begin{tabular}{|l|c|c|c|}
\hline \multirow{2}{*}{ Hydrological year } & \multicolumn{3}{|c|}{ The sum of rainfall [mm] } \\
\cline { 2 - 4 } & winter half-year & summer half-year & whole year \\
\hline 2008 & 406 & 173 & 579 \\
\hline 2009 & 177 & 433 & 610 \\
\hline 2010 & 202 & 432 & 634 \\
\hline 2011 & 307 & 325 & 632 \\
\hline 2012 & 219 & 374 & 593 \\
\hline $1961-2000$ & 196 & 331 & 527 \\
\hline
\end{tabular}

TABLE 2. The half-year and annual average unit outflow $-q_{S Q}$ of the Wielka Struga River catchment in the period 2008-2012 (Bańkowska et al. 2011; Popek et al. 2011)

\begin{tabular}{|l|c|c|c|}
\hline \multirow{2}{*}{ Hydrological year } & \multicolumn{3}{|c|}{ Average unit outflow $-q_{S Q}\left[1 \cdot \mathrm{s}^{-1} \cdot \mathrm{km}^{-2}\right]$} \\
\cline { 2 - 4 } & winter half-year & summer half-year & whole year \\
\hline 2008 & 2.16 & 0.60 & 1.38 \\
\hline 2009 & 2.21 & 0.42 & 1.25 \\
\hline 2010 & 4.74 & 2.53 & 3.63 \\
\hline 2011 & 8.08 & 0.84 & 4.44 \\
\hline 2012 & 1.43 & 0.37 & 0.90 \\
\hline
\end{tabular}

TABLE 3. The volume of water supplied to the Zdworskie Lake in 2008-2012 (Bańkowska et al. 2011; Popek et al. 2011)

\begin{tabular}{|l|c|c|c|c|}
\hline \multirow{2}{*}{ Hydrological year } & \multicolumn{2}{|c|}{$\begin{array}{c}\text { The volume of the inflow from all sources } \\
\text { [thousand of } \mathrm{m}^{3} \text { ] }\end{array}$} & $\begin{array}{c}\text { Total vercentage of total inflow [\%] } \\
\text { the inflow } \\
\text { [thousand of } \mathrm{m}^{3} \text { ] }\end{array}$ \\
\cline { 2 - 4 } & $\begin{array}{c}\text { Wielka Struga } \\
\text { River }\end{array}$ & $\begin{array}{c}\text { streams } \\
\text { A, B and C }\end{array}$ & artificial supply & \\
\hline 2008 & $965(48.0 \%)$ & $23(1.2 \%)$ & $1,021(50.8 \%)$ & 2,009 \\
\hline 2009 & $848(53.7 \%)$ & $0(0.0 \%)$ & $731(46.3 \%)$ & 1,579 \\
\hline 2010 & $2,455(91.6 \%)$ & no data & $256(9.4 \%)$ & 2,711 \\
\hline 2011 & $3064(100 \%)$ & no data & $0(0,0 \%)$ & 3,064 \\
\hline 2012 & $627(77.8 \%)$ & $22(2.7 \%)$ & $157(19.5 \%)$ & 805 \\
\hline
\end{tabular}

supplied to the Zdworskie Lake by pipeline from the Dobrzyków Canal. In 2008 and 2009, when the supply conditions of the lake from Wielka Struga River catchment were poor, the volume of water pumped from Dobrzyków made about $50 \%$ of the total volume of inflow to the lake. During the floods in the Iłowsko-Dobrzykowska Valley in May 2010 (as a result of flood embankment breakdown of the Vistula River in Świniary) pumping station in the Dobrzyków was damaged. As a consequence the lake could not be artificially supplied till the end of 
2011. In 2012 only about $20 \%$ of the total volume of inflow to the lake was delivered via pipeline.

The conditions of the outflow from the lake, controlled in gauge cross-section the Wincentów (Fig. 1), were closely related to the terms of inflow to the Zdworskie Lake. Table 4 summarizes the duration and volume of the outflow and its percentage with respect to the volume of the inflow. The most favorable situation, in terms of the exchange degree of water in the lake, was observed in so-called wet years 2010 and 2011 (the most rich in water), when about $72-88 \%$ volume of the inflow flowed away from

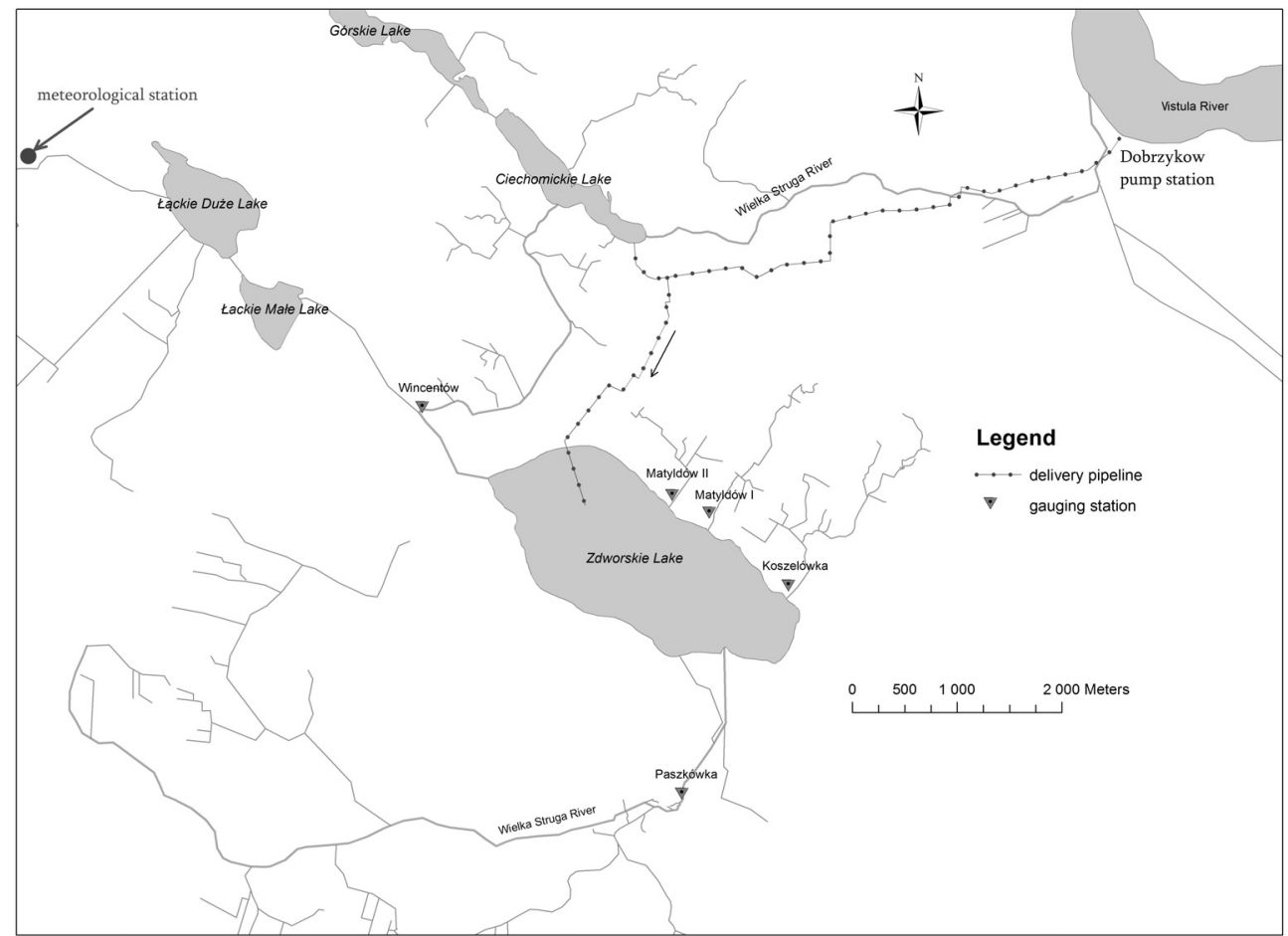

FIGURE 1. Location of the gauging station in the Wielka Struga River

TABLE 4. The comparison of the outflow volume from the Zdworskie Lake in 2008-2012 (Bańkowska et al. 2011; Popek et al. 2011)

\begin{tabular}{|c|c|c|c|}
\hline Hydrological year & Outflow duration [day] & $\begin{array}{c}\text { Volume of outflow } \\
\text { [thousand of } \mathrm{m}^{3} \text { ] }\end{array}$ & Percentage of inflow [\%] \\
\hline 2008 & 153 & 681 & 33.9 \\
\hline 2009 & 118 & 112 & 6.9 \\
\hline 2010 & 329 & 1,758 & 71.6 \\
\hline 2011 & 184 & 2,703 & 88.2 \\
\hline 2012 & 42 & 25 & 3.2 \\
\hline
\end{tabular}


the lake down the Wielka Struga River. Especially good conditions for the water exchange in the lake occurred in 2010, because the outflow lasted nearly 11 months (329 days). The worst situation was in 2012, when the outflow from the lake appeared only for 42 days and it represented only $3.2 \%$ of the inflow volume. The calculations of the water balance of the Zdworskie Lake in the hydrological years 2008-2012 were carried out according to formula (1) for monthly intervals, i.e. a total of 60 periods. The results of the total water balance for the half-year periods are shown in Table 5. Full results of the water balance calculations in a monthly intervals (for years 2008-2011) are included in the paper of Sławińska (2013).

Table 5 summarizes the observed change in lake retention, determined on the basis of changes in water levels observed in the gauge cross-section the Wincentów. Comparison of retention determined by balance calculations and measurements of water levels in the lake are also shown in Figure 2 and 3. Significant differences between the calculated and the measured change of retention indicate intense outflow of the lake water to the ground. Water losses due to ground drainage, calculated on the basis of the difference $\Delta R-\Delta R_{m}$ (Table 5), ranged from $761,000 \mathrm{~m}^{3}$ in 2010 to $2,078,000 \mathrm{~m}^{3}$ in 2008 .

Possibility of ground drainage is confirmed by geological surveys (Denis 2006) showing that under a layer of organic sediments at the bottom of the Zdworskie Lake occur a layer of fine and medium sands, with minor part of sand-gravel and gravel. The height configuration of the roof of the underlying impermeable clay and silt layer is in the lake surrounding clearly differentiated. The ground drainage may occur in the northern part of the lake, while in the south part additional ground water supply is possible.The diversity of the ground inflow and outflow in different parts of the lake can be proved by observations of the lake water level fluctua-

TABELA 5. The results of the total water balance of the Zdworskie Lake for the half-year and year periods in the years of 2008-2012 (Bańkowska et al. 2011; Popek et al. 2011)

\begin{tabular}{|c|c|c|c|c|c|c|c|c|c|c|}
\hline \multirow[t]{2}{*}{ Year } & \multirow{2}{*}{$\begin{array}{l}\text { Half- } \\
\text {-year }\end{array}$} & \multicolumn{5}{|c|}{$\begin{array}{l}\text { Components of the water balance } \\
{[\mathrm{mm}]}\end{array}$} & \multirow{2}{*}{$\begin{array}{c}\Delta R_{m} \\
{[\mathrm{~mm}]}\end{array}$} & \multirow{2}{*}{$\begin{array}{c}\Delta R-\Delta R_{m} \\
\quad[\mathrm{~mm}]\end{array}$} & \multicolumn{2}{|c|}{$\begin{array}{l}\text { Ground outflow } \\
\text { [thousand of } \mathrm{m}^{3} \text { ] }\end{array}$} \\
\hline & & $H_{d}$ & $H_{o}$ & $P$ & $E_{w}$ & $\Delta R$ & & & half-year & year \\
\hline \multirow{2}{*}{2008} & winter & 362 & 165 & 406 & 70 & 533 & 190 & 343 & 1,176 & \multirow{2}{*}{2,078} \\
\hline & summer & 224 & 34 & 173 & 512 & -149 & -412 & 263 & 902 & \\
\hline \multirow{2}{*}{2009} & winter & 292 & 22 & 177 & 113 & 334 & 299 & 35 & 120 & \multirow{2}{*}{768} \\
\hline & summer & 167 & 11 & 433 & 486 & 103 & -86 & 189 & 648 & \\
\hline \multirow{2}{*}{2010} & winter & 476 & 160 & 202 & 97 & 421 & 190 & 231 & 792 & \multirow{2}{*}{761} \\
\hline & summer & 240 & 352 & 432 & 362 & -42 & -33 & -9 & -31 & \\
\hline \multirow{2}{*}{2011} & winter & 809 & 785 & 307 & 86 & 245 & 87 & 158 & 542 & \multirow{2}{*}{919} \\
\hline & summer & 85 & 3 & 325 & 423 & -16 & -126 & 110 & 377 & \\
\hline \multirow{2}{*}{2012} & winter & 151 & 5 & 219 & 100 & 265 & 131 & 134 & 459 & \multirow{2}{*}{1,069} \\
\hline & summer & 84 & 2 & 374 & 505 & -49 & -227 & 178 & 610 & \\
\hline
\end{tabular}


tions close to each gauge cross-sections: the hydrological year 2011. Although the Koszelówka - on estuarine section of observations in streams A and C are not stream A and the Matyldów-2 - on estua- complete (due to the failure of the water rine section of stream C (Fig. 1). Figure level sensor), Figure 4 shows that in the 4 shows the comparison of hydrographs cross-section the Koszelówka water levof water table elevation in the lake and els (or in the absence of flow - groundin the sections mentioned above during water elevations) were higher than the

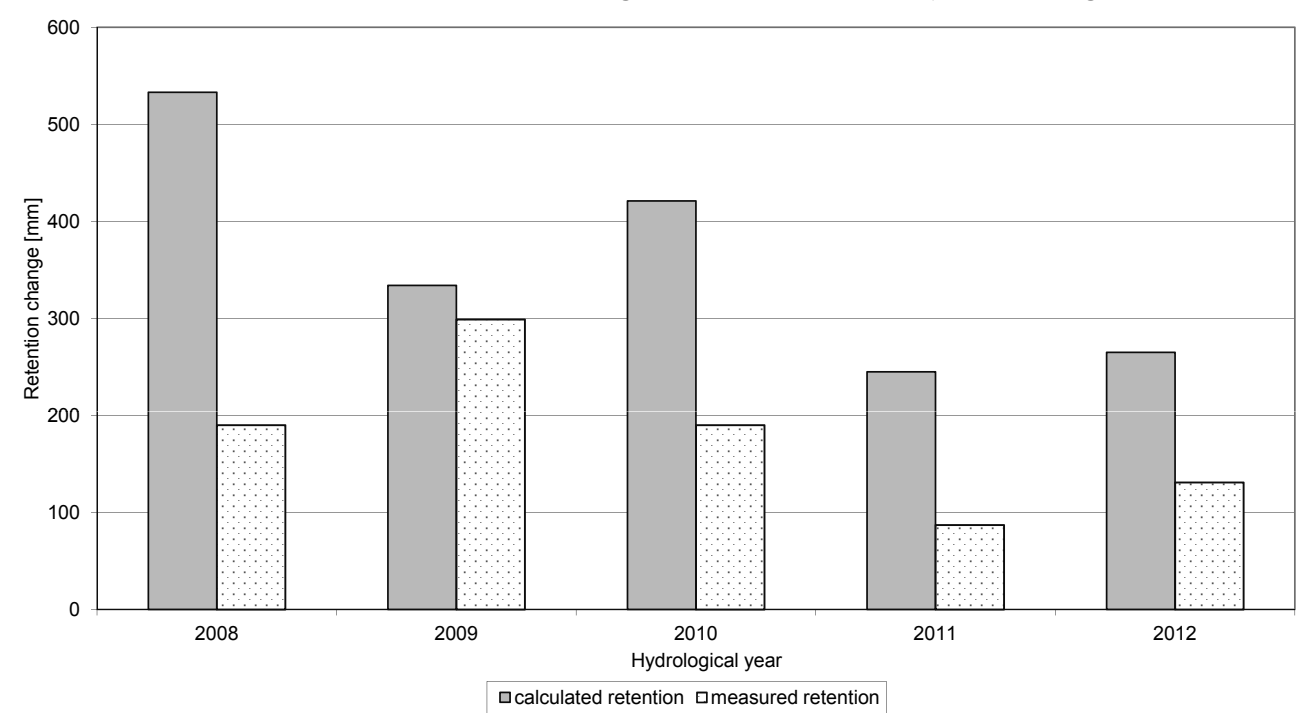

FIGURE 2. Retention changes in the winter half-years

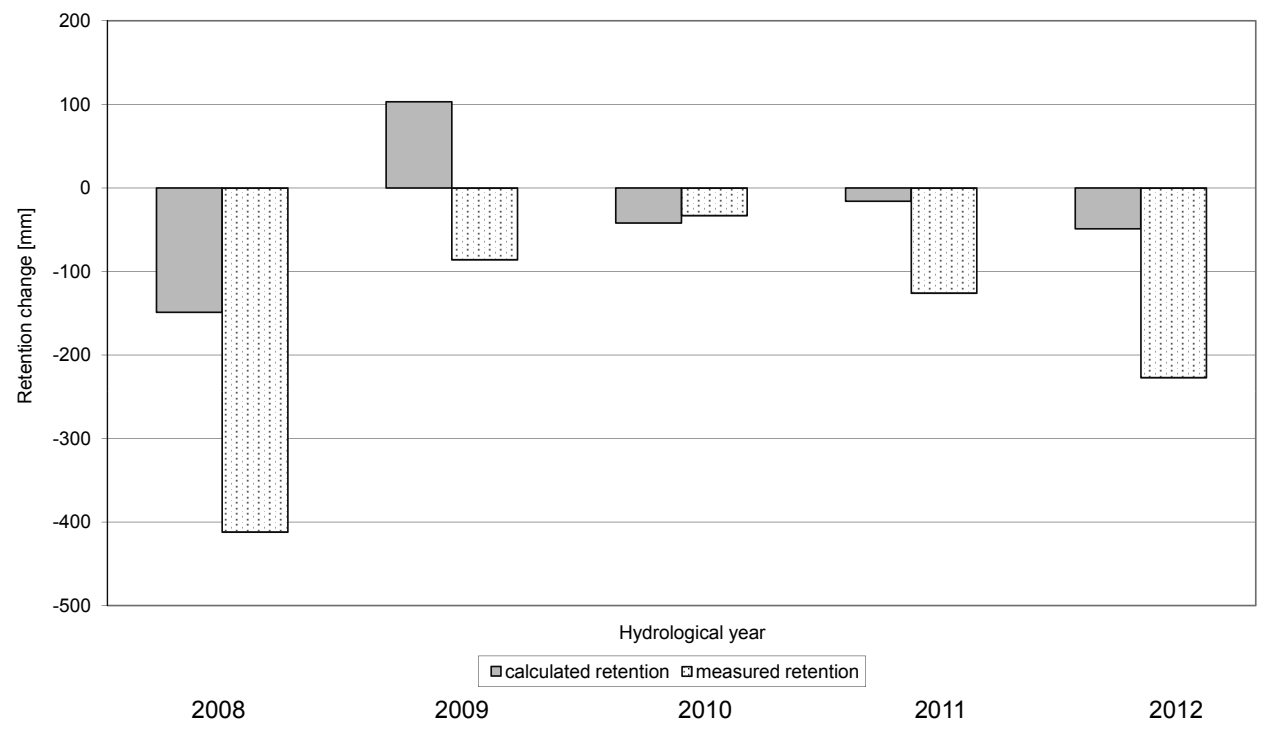

FIGURE 3. Retention changes in the summer half-years 


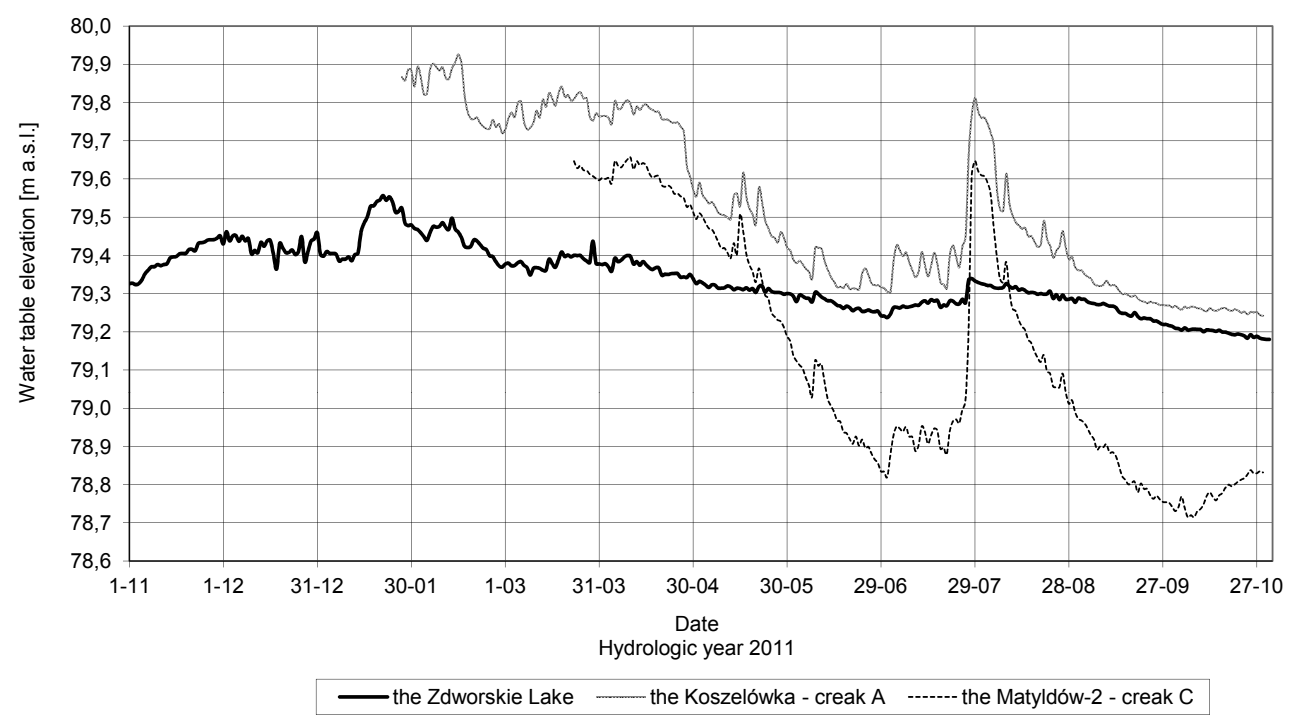

FIGURE 4. Comparison of water table elevation in the Zdworskie Lake and surface / groundwater elevations in creaks A (the Koszelwka gauge station) and C (the Matyldów-2 gauge station) during hydrologic year 2011

water table elevations in the Zdworskie Lake. Constantly occurring hydraulic gradient in gauge cross-section the Koszelówka indicates groundwater supply in this part of the lake. In the case of gauge cross-section the Matyldów-2 changes of the water surface elevation indicate that there are periods of both: supply of lake by flow in the stream $C$ or groundwater and ground drainage, when the water table elevations in the lake are clearly higher than in the ground.

\section{CONCLUSIONS}

The results of hydrological studies carried out in 2008-2012 in the Wielka Struga River catchment and in the Zdworskie Lake allow to form the following conclusions:

- The study area is characterized by its own small water resources show- ing a large annual variation - most of the outflow from the Wielka Struga River catchment to the Zdworskie Lake takes place in the winter half-year, when the outflow is $2-10$ times higher than in the summer half-year.

- The replenishment of water deficits through artificial supply of the lake, especially in the summer, is essential for the functioning of the lake ecosystem in the existing hydrological conditions.

- The results of the water balance calculations and observations in gauge cross-section the Matyldów-2 has indicated the periodic water outflow of the lake to the ground layers in the northern part of the Zdworskie Lake. However, in the southern part of the lake geological and hydrological observations in gauge cross-section the Koszelówka indicate the presence of additional ground water supply of the 
lake. The calculated amount of water loss due to the ground outflow, ranging from $761,000 \mathrm{~m}^{3}$ in 2010 to $2,078,000 \mathrm{~m}^{3}$ in 2008 , should be treated as total values - covering both groundwater supply and groundwater outflow of the lake into the ground.

- Accurate identification of the geological conditions and the amount of inflow/outflow of groundwater requires a detailed hydrogeological studies in the immediate catchment of the Zdworskie Lake.

\section{REFERENCES}

ALLEN, R.G., PEREIRA L.S., RAES D., SMITH M. 1998: Crop evapotranspiration: Guidelines for computing crop water requirements FAO. Irrigation and Drainage Paper 56.

BAŃKOWSKA A., WASILEWICZ M. 2008: Przegląd działań realizowanych w celu poprawy stanu Jeziora Zdworskiego. Przeglad Naukowy Inżynieria i Ksztaltowanie Srodowiska 1 (39), 80-90.

BAŃKOWSKA A., POPEK Z., WASILEWICZ M. 2010: Diagnoza stanu zbiornika i kierunki działań rekultywacyjnych Jeziora Zdworskiego - Bilans wodny i głównych pierwiastków biogenicznych. Przeglad Komunalny 10, 69-74.

BAŃKOWSKA A., SAWA K., POPEK Z., WASILEWICZ M. 2011: Analiza wyników monitoringu ilości i jakości wód zasilających Jezioro Zdworskie w aspekcie jego rekultywacji. Przeglad Naukowy Inżynieria i Ksztattowanie Srodowiska 20 (2), 84-96.

DENIS K. 2006. Wyniki badań osadów $w$ dnie Jeziora Zdworskiego $w$ gm. Lack, pow. ptocki, dla potrzeb jego renaturyzacji. Zakład Badań Geologicznych i Usług Inżynieryjnych „Geobad”, Słupno (unpublished).
GUTRY-KORYCKA M. 1978: Parowanie terenowe w Polsce (1931-1960). Przeglad Geograficzny XXI (XXIX), 1, 295-299.

IMGW 1987: Atlas hydrologiczny Polski. Wydawnictwo Geologiczne, Warszawa.

KAWAŁCZEWSKA J. 2009: Narodziny inicjatywy społecznej. In: J. Nasiadko (ed.) O przyszłość Pojezierza Łackiego. Regionalne Centrum Edukacji Ekologicznej, Płock, 11-17.

LENART W., POPEK Z. 2009: Fizjografia Pojezierza Łąckiego. In: J. Nasiadko (ed.) O przyszłość Pojezierza Lackiego. Regionalne Centrum Edukacji Ekologicznej, Płock, 19-44.

POPEK Z. 2009: Badania i zabiegi dotyczące bilansu wodnego zlewni. In: J. Nasiadko (ed.) O przyszłość Pojezierza Lackiego. Regionalne Centrum Edukacji Ekologicznej, Płock, 87-103.

POPEK Z., BAŃKOWSKA A., WASILEWICZ M. 2011: Monitoring ilości i jakości wód dopływajacych do Jeziora Zdworskiego. Raport końcowy z badań. Katedra Inżynierii Wodnej SGGW, Warszawa (unpublished).

SŁAWAŃSKA W. 2013: Charakterystyka warunków hydrologicznych $w$ Jeziorze Zdworskim. Wydział Budownictwa i Inżynierii Środowiska SGGW, Warszawa. Manuscript.

WIŚNIEWSKI R. 2009: Badania i zabiegi dotyczące osadów jeziornych. In: J. Nasiadko (ed.) O przyszłość Pojezierza Łackiego. Regionalne Centrum Edukacji Ekologicznej, Płock, 104-115.

WIŚNIEWSKI B., WOLSKI T., BUCHOLZ W., KREFT A. 2007: Bilanse wód Jeziora Dąbie. Infrastruktura i Ekologia Terenów Wiejskich 4 (2), 211-221.

Streszczenie: Bilans wodny Jeziora Zdworskiego wokresie 2008-2012. W pracy przedstawiono wyniki obliczeń bilansu wodnego dla Jeziora Zdworskiego, wykonane na podstawie danych meteorologicznych i hydrologicznych z lat 2008-2012. Dane meteorologiczne pochodzą $z$ automatycznej stacji pomiarowej należącej do Lasów Państwowych, 
zlokalizowanej koło Łącka, w odległości około $7,5 \mathrm{~km}$ od geometrycznego środka Jeziora Zdworskiego. Natomiast dane hydrologiczne pochodzą z 5 posterunków wodowskazowych, założonych w zlewni Wielkiej Strugi i Jeziora Zdworskiego przez Katedrę Inżynierii Wodnej SGGW do badań monitoringowych realizowanych w ramach Programu renaturyzacji jezior Pojezierza Łąckiego. $\mathrm{Na}$ podstawie wyników obliczeń bilansowych stwierdzono, że w całym analizowanym okresie objętości wody zretencjonowanej w Jeziorze Zdworskim powinny być znacznie większe od zaobserwowanych. Warunki geologiczne w części bezpośredniej zlewni jeziora a także wyniki pomiarów stanu wody gruntowej w jednym z przekrojów wodowskazowych świadczą o okresowym odpływie wód jeziornych do gruntu podłoża. W latach 2008-2012 roczne straty wody w Jeziorze Zdworskim spowodowane odpływem do gruntu były zróżnicowane i wyniosły od około 761 do 2078 tys. $\mathrm{m}^{3}$.
Stowa kluczowe: bilans wodny jeziora, zasilanie jezior, Jezioro Zdworskie

MS. received 28 June 2013

\section{Authors' addresses:}

Katedra Inżynierii Wodnej, Wydział Budownictwa i Inżynierii Środowiska SGGW

ul. Nowoursynowska 166

02-787 Warszawa, Poland

e-mail: zbigniew_popek@sggw.pl

michal_wasilewicz@sggw.pl

agnieszka_bankowska@sggw.pl

Andrzej Boczoń

Zakład Ekologii Lasu

Instytut Badawczy Lasu

ul. Braci Leśnej 3

05-090 Sękocin Stary, Raszyn, Poland

e-mail: a.boczon@ibles.waw.pl 